\title{
Analisis Model Komunikasi Pada Partai Politik Lokal Dan Partai Politik Nasional di Dewan Perwakilan Rakyat Aceh
}

\author{
Irpannusir $^{1^{*}}$, Iskandar Zulkarnain ${ }^{2}$, Rahmanita Ginting ${ }^{3}$ \\ Dewan Perwakilan Rakyat Aceh, Jl. Tgk. H.M. Daud Beurueh, Banda Aceh dan \\ Pascasarjana Universitas Muhammadiyah Sumatera Utara, Jl. Denai, Kota Medan \\ ${ }^{*}$ Koresponden: irpan.nusir2@gmail.com
}

\begin{abstract}
Abstrak
Terbaginya partai politik dalam dua kelompok yang berbeda, yaitu partai politik lokal dan partai politik nasional di Dewan Perwakilan Rakyat Aceh menciptakan sebuah model komunikasi dalam interaksi mereka. Dimana mereka yang berasal dari Partai nasional tidak akan memasukkan diri untuk melakukan komunikasi terhadap isu lokal. Sebaliknya, mereka yang berasal dari partai lokal akan menarik diri untuk membahas isu nasional. Model komunikasi tersebut menjadi kajian dalam penelitian ini, dengan menggunakan paradigma alamiah. Metode penelitian yang digunakan adalah dekriptif dengan pendekatan kualitatif. Teknik pengumpulan data dilakukan dengan wawancara dan observasi. Dengan model komunikasi yang dilakukan kedua partai politik tersebut membuat masingmasing merasa benar atau disebut dengan pandangan apriori. Akibatnya, diantara kedua kelompok partai tersebut kurang menimbulkan kepekaan, kurang menunjukkan solidaritas, kurang adanya keterbukaan dan kurang kerjasama.
\end{abstract}

Kata kunci: Model Komunikasi, Partai Politik, Dewan Perwakilan Rakyat Aceh.

\begin{abstract}
The division of political parties in two different groups, that is, local political parties and national political parties in the Aceh House of People's Representative created a communication model in their interactions. Where those from the national party will not enter themselves to communicate with local issues. Instead, those from local parties will withdraw to discuss national issues. The communication model will be studied in this research, by using a natural paradigm. The research method used is descriptive with a qualitative approach. Data collection techniques are done by interview and observation. With the communication model carried out by the two political parties, each one feels right or is called apriori view. As a result, the two groups of parties are less sensitive, show less solidarity, lack of openness and lack of cooperation.
\end{abstract}

Keywords: Communication Model, Political Parties, Aceh House of People's Representative.

\section{PENDAHULUAN}

Kesepakatan damai antara Pemerintah Republik Indonesia (RI) dengan Gerakan Aceh Merdeka (GAM), yang tertuang dalam MoU Hels inki dan Undang-Undang (UU) Nomor 11 Tahun 2006 tentang Undang-Undang Pemerintahan Aceh (UUPA) menjadi awal bagi penyelenggaraan pemerintahan dengan aturan yang baru. Salah satunya, terkait dengan dibolehka nnya partai lokal ikut sebagai peserta kontestasi demokrasi di Aceh, sejajar dengan partai nasional yang lebih dahulu ada. Keberadaan partai politik lokal di Aceh juga didukung oleh masyarakatnya yang dibuktikan pada saat pemilihan legislatif wilayah pemilihan Provinsi Aceh tahun 2019 silam, Partai Aceh sebagai partai lokal mendulang suara terbanyak (21.16\%) mengalahkan suara partai nasional yang ikut bursa pemilihan legis latif saat itu. Dengan perolehan suara ini, menempatkan partai lokal sebagai pemegang pengaruh besar di Dewan Perwakilan Rakyat Aceh.

Kemenangan dan dukungan dari masyarakat tidak lantas membuat partai politik lokal dapat diterima sebagai koalisi yang utuh oleh parta politik nasional. Kedua kelompok partai 
Vol 3No. 1, 2020, 37-46

DOI: $10.30596 /$ persepsi.v\%vi\% i.4444

politik tersebut saling menunjukkan ego dan kepentingan kelompoknya. Dimana partai lokal berusaha melakukan upaya untuk memperjuangkan aturan berasas kearifan lokal yang sebenarnya telah dituangkan dalam UUPA, yang dipertegas dalam Qanun Aceh atau peraturan daerah yang mengatur tentang tata pemerintahan dan kehidupan masyarakat di provinsi Aceh. Sering kali, Qanun yang diperjuangkan oleh partai lokal menjadi sebuah bahasan dile ma bagi partai nasional. Mereka tidak menolak tapi juga tidak menerima. Sebab, partai nasional memang membatasi diri untuk persoalan semacam itu. Pembatasan diri dari masingmasing kelompok partai inilah yang kemudian memunculkan model komunikasi antara partai politik lokal dan partai politik nasional di Dewan Perwakilan Rakyat Aceh.

\section{Komunikasi Politik}

Memahami komunikasi politik pada prinsipnya adalah pengembangan dari komunikasi. Secara sederhana Harold Lasswell dalam karyanya, The Structure and Function of Communication in Society. Ia mengemukakan bahwa komunikasi (Effendy, 2005: 10) adalah Who Says What in Which Channel To Whom With What Effect atau siapa yang menyampaikan, apa yang disampaikan, melalui apa, kepada siapa, dan apa pengaruhnya. Pengertian komunikasi seperti yang diutarakan Laswell dapat digambarkan dalam model sebagai berikut:

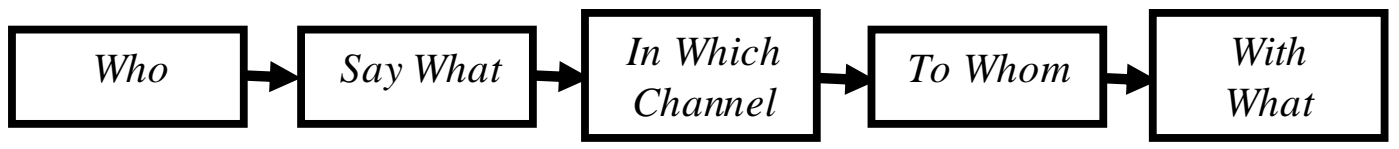

Gambar 1. Model komunikasi Harold Lasswell (Effendy, 2005: 10).

Who dapat diartikan sebagai sumber atau komunikator. Yaitu, pihak yang meiliki kebutuhan untuk berkomunikasi dan yang memulai suatu komunikasi, bisa seorang individu, kelompok, organisasi, maupun suatu negara sebagi komunikator. Say what dapat dipahami sebagai apa yang akan disampaikan atau dikomunikasikan kepada komunikan (penerima), dari komunikator (sumber) atau isi informasi. apa yang akan disampaikan kepada penerima (komunikan), dari sumber (komunikator) atau isi informasi. Merupakan seperangkat simbol verbal/non verbal yang mewakili perasaan, nilai, gagasan/maksud sumber tadi. In which channel adalah saluran yang digunakan untuk menyampaikan pesan dari komunikator (sumber) kepada komunikan (pe nerima) baik secara langsung (tatap muka) maupun tidak langsung (melalu media cetak/elektronik). To whom adalah penerima pesan. Siapa saja dapat menjadi komunikan, baik individu, kelompok, organisasi atau suatu negara yang menerima pesan dari sumber. Hal tersebut dapat disebut tujuan (destination), pendengar (listener), khalayak (audience), komunikan, penafs ir, penyandi balik (decoder). Terakhir adalah with what effect atau efek yang terjadi pada komunikan (penerima) seteleh menerima pesan dari komunikator, misalnya perubahan sikap, tingkah laku atau bertambahnya pengetahuan.

Komunikasi politik adalah proses penyampaian pesan mengenai politik dari pemerintah kepada masyarakat atau sebaliknya, dari masyarakat kepada pemerintah (Surbakti, 2010:152). Komunikasi politik (Rush, 2008: 24) juga dapat diartikan sebagai proses informasi politik yang relevan diterus kan dari satu bagian sistem politik kepada bagian lainnya, dan di antara sistem-sistem sosial dengan sistem-sistem politik. Komunikasi politik (Harun dan Sumarno, 2006: 3) adalah suatu proses dan kegiatan membentuk sikap dan perilaku politik yang terintegrasi ke dalam suatu sistem politik dengan menggunakan simbolsimbol yang berarti.

Berdasarkan definisi tersebut, dapat diketahui bahwa dalam komunikasi politik terdapat unsur pokok komunikasi politik yang meliputi komunikator politik, komunikan, isi komunikasi (pesan), me dia komunikasi, tujuan komunikasi, sumber dan efek. Komunikator 
politik pun bisa menunjuk pada badan atau institusi (Harun dan Sumarno, 2006: 6). Peran Komunikator politik menjadi sangat penting. Dan Nimmo menggaris bawahi, komunikator politik memainkan peran sosial yang utama, dalam proses opini publik. Dia mengidentifikasi mereka berdasarkan kedudukan dalam masyarakat menjadi tiga kategori yaitu politikus yang bertindak sebagai komunikator politik, komunikator profesional dalam politik, dan aktivis atau komunikator paruh waktu (Nimmo, 1978: 16).

Pesan politik ialah pernyataan yang disampaikan, baik secara tertulis, secara verbal maupun non verbal, tersembunyi atau terang-terangan, baik yang disadari maupun tidak disadari yang isinya mengandung bobot politik. Selanjutnya, saluran atau media politik ialah alat atau sarana yang digunakan oleh para komunikator dalam menyampaikan pesan-pesan politiknya. Saluran atau me dia yang digunakan bentuknya bisa beraneka ragam seperti media massa, cetak, elektronik. Serta bisa pula menggunakan media teknologi informasi seperti internet, face book dan sebagainya. Di luar media, berbagai saluran komunikasi la innya seperti saluran komunikasi kelompok, saluran komunikasi publik, saluran komunikasi sosial. Saluran komunikasi kelompok misalnya, partai politik, (DPP, DPW, DPD, DPC, DPAC), organisasi profesi, ikatan alumni, organisasi sosial keagamaan, karangtaruna, kelompok pengajian, ke lompok tani dan ne layan, koperasi, dan sebaga inya. Saluran komunikasi publik misalnya, aula, balai desa, alun-alun, dan sebagainya. Saluran komunikasi sosial misalnya pesta perkawinan, acara arisan, dan sebagainya. Sedangkan sasaran adalah anggota masyarakat yang diharapkan dapat memberikan dukungan dalam bentuk pemberian suara (vote) kepada partai atau kandidat da lam pemilihan umun. Terakhir, Efek komunikasi politik (Cangara, 2009: 33) yang diharapkan adalah terciptanya pemahaman terhadap sistem pemerintahan dan partai-partai politik, yang nuansanya bermuara pada pemberian suara (vote) dalam pemilihan umum.

\section{Partai Politik}

Miriam Budiarjo (2006: 160), mendefinisikan bahwa partai politik adalah suatu kelompok yang terorganisir yang anggota-anggotanya mempunyai orientasi, nilai-nilai dan cita-cita yang sama. Tujuan kelompok ini ialah memperoleh kekuasaan politik dan merebut kedudukan politik biasanya dengan cara konstitusional untuk melaksanakan kebijakankebijakan. Miriam juga menye butkan bahwa fungsi dari partai politik adalah sebagai berikut:

1. komunikasi politik, yaitu fungsi menyalurkan berbagai macam pendapat dan aspirasi masyarakat ditengah keberagaman pendapat masyarakat modern yang terus berkembang. Pendapat atau aspirasi seseorang atau suatu kelompok akan hilang tidak berbekas apabila tidak ditampung dan digabung dengan pendapat dan aspirasi orang lain yang senada, proses tersebut dinamakan (interest aggregation). Setelah penggabungan pendapat dan aspirasi tersebut diolah dan dirumuskan sedemikian rupa sehingga kesimpangsiuran pendapat dalam masyarakat berkurang (interest articulation).

2. Sosialisasi politik, yaitu sebuah proses dimana seseorang memperoleh sikap dan orientasi terhadap fenomena politik yang umumnya berlaku da lam masyarakat dimana dia berada. Proses ini merupakan faktor penting dalam terbentuknya budaya politik (political culture) suatu bangsa karena proses penyampaiannya tersebut berupa norma-norma dan nilai-nilai dari suatu generasi ke generasi berikutnya.

3. Rekruitmen politik, yaitu fungsi untuk mempersiapkan kepemimpinan internal maupun nasional karena setiap partai membutuhkan kader-kader yang berkualitas untuk dapat mengembangkan partainya. Rekrutmen politik menjamin kontinuitas dan kelestarian partai, sekaligus merupakan salah satu cara untuk menjaring dan melatih calon-calon pemimpin. 
4. Pengatur konflik politik, yaitu fungsi untuk membantu mengatasi konflik diantara masyarakat atau sekurang-kurangnya dapat diatur sedemikian rupa sehingga akibat negatifnya dapat ditekan seminimal mungkin. Pendapat lain menurut ahli Arend Lijphart (Rahman, 2007: 103-104) perbedaan-perbedaan atau perpecahan ditingkat massa bawah dapat diatasi oleh kerja sama diantara elite-elite politik. Dalam konteks kepartaian, para pemimpin partai adalah e lite politik.

\section{Partai Politik Lokal}

Kajian dalam penelitian ini membedakan partai politik menjadi dua kelompok yaitu partai politik lokal dan partai politik nasional. Partai lokal sendiri sebenarnya juga sudah diatur dalam Undang-Undang Republik Indonesia (2006: 11) ada lah organisasi politik yang dibentuk oleh sekelompok warga negara Indonesia yang berdomisili di Aceh secara sukarela atas dasar persamaan kehendak dan cita-cita untuk memperjuangkan kepentingan anggota, masyarakat, bangsa dan negara melalui pemilihan anggota Dewan Perwakilan Rakyat Aceh/Dewan Perwakilan Rakyat Kabupaten/Kota, Gebernur/Wakil Gebernur, bupati/wakil bupati dan walikota/wakil walikota.

Lahirnya partai lokal juga merupaka amant yang tertuang dalam UU No.32 Tahun 2004 juga mengatur tentang pemerintahan daerah. Sebagaimana yang dite gaskan dalam Pasal 1 ayat (5) yang menyatakan bahwa otonomi daerah adalah hak, kekuasaan, dan kewajiban daerah otonom untuk mengatur dan mengurus sendiri urusan pemerintahan dan kepentingan masyarakat setempat sesuai dengan peraturan perundang-undangan.

Partai politik lokal tujuan umum, yakni mewujudkan cita-cita nasional bangsa Indonesia, mengembangkan kehidupan demokrasi berdasarkan Pancasila dengan menjunjung tinggi kedaulatan rakyat dalam NKRI dan mewujudkan kesejahteraan bagi seluruh masyarakat Aceh. Sedangkan tujuan khusus partai politik lokal adalah meningkatkan partisipasi politik masyarakat Aceh dalam rangka penyelenggaraan pemerintahan daerah dan memperjuangkan cita-cita partai politik lokal dalam kehidupan bermasyarakat, berbangsa dan bernegara sesuai kekhususan dan keistimewaan Aceh Partai politik lokal berfungsi sebagai sarana pendidikan politik bagi anggota dan masyarakat, penciptaan iklim yang kondusif bagi persatuan dan kesatuan bangsa Indonesia untuk kese jahteraan rakyat, penyerap, penghimpun dan penyalur aspirasi politik rakyat dan partisipasi politik rakyat.

\section{Partai Politik Nasional}

Undang-Undang Nomor 2 Tahun 2008 tentang partai politik pasal 1 ayat 1, partai politik didefinisikan sebagai organisasi yang bersifat nasional dan dibentuk oleh sekelompok warga negara Indonesia secara sukarela atas dasar kesamaan kehendak dan cita-cita untuk memperjuangkan dan me mbe la kepentingan politik anggota, masyarakat, bangsa dan negara, serta mempe lihara keutuhan Negara Kesatuan Republik Indonesia berdasarkan Pancasila dan Undang-Undang Dasar Negara Kesatuan Republik Indonesia Tahun 1945.

Selanjutnya, Undang-Undang Republik Indonesia Nomor 42 Tahun 2008 tentang Pemilihan Umum Presiden dan Wakil Presiden pada Bab I Ketentuan Umum Pasal 1, Poin 2 Partai politik adalah partai politik yang telah ditetapkan sebagai peserta pemilu anggota Dewan Perwakilan Rakyat.

Tujuan umum partai politik adalah mewujudkan cita-cita nasional bangsa Indonesia, menjaga dan memelihara keutuhan NKRI, mengembangkan kehidupan demokrasi berdasarkan Pancasila dengan menjunjung tinggi kedaulatan rakyat dalam Negara Kesatuan Republik Indonesia, dan mewujudkan kesejahteraan bagi seluruh rakyat Indonesia. Sedangkan tujuan khusus adalah meningkatkan partisipasi politik anggota dan masyarakat dalam rangka penyelenggaraan kegiatan politik dan pemerintahan, memperjuangkan cita-cita partai politik dalam kehidupan bermasyarakat, berbangsa dan bernegara, dan membangun 
etika dan budaya politik dalam kehidupan bermasyarakat, berbangsa dan bernegara (Peraturan pemilu 2014:9).

\section{Batasan Masalah}

1. Partai lokal yang dimaksud dalam penelitian ini adalah Partai Aceh (PA) dan Partai Nanggroe Aceh (PNA).

2. Partai nasional yang dimaksud dalam penelitian ini adalah Partai Gerindra dan PKS.

\section{METODE PENELITIAN}

Kajian penelitian ini menggunakan paradigma alamiah (naturalistic paradigm). Menurut Arikunto (2006: 12), paradigma alamiah merupakan cara pandang dengan melihat fakta terjadi secara alamiah, dalam situasi normal dan tidak dimanipulasi keadaan dan kondisinya. Paradigma ini bersumber pada pandangan fenomenologis yang berusaha memahami perilaku manusia dari segi konsep berpikir maupun bertindak para manusia yang menjadi subjek peneliti.

Metode penelitian yang digunakan dalam penelitian ini adalah dekriptif dengan pendekatan kualitatif. Metode penelitian tersebut merupakan sebuah metode dalam mene liti dengan memahami fenomena tentang apa yang dialami oleh subyek pene litian secara holistik dan dengan cara mendeskripsikan dalam bentuk kata-kata dan bahasa pada suatu konteks khusus yang alamiah atau dengan memanfaatkan berbagai metode ilmiah. Jenis penelitian kualitatif (Sugiono, 2006: 9) dijelaskan sebagai metode penelitian yang berlandaskan pada filsafat post positivisme. Ini digunakan untuk pene litian pada kondisi objek alamiah. Dengan memakai metode ini, peneliti menjadi instrumen kunci, teknik pengumpulan data dengan triangulasi, analisis data bersifat induktif atau kualitatif dan hasil penelitian kualitatif lebih menekankan makna dari pada genera lisasi.

\section{HASIL DAN PEMBAHASAN}

Di Provinsi Aceh khususnya di dalam Gedung Dewan Perwakilan Rakyat Aceh, partai-partai yang ada dapat dikelompokkan ke dalam dua golongan, yaitu partai lokal dan partai nasional. Hasil analisis peneliti menunjukkan bahwa, komunikasi yang terjadi di lingkungan Dewan Perwakilan Rakyat Aceh, lumrahnya sama seperti apa yang dikemukanakan oleh Harold Lasswell, yaitu Who Says What in Which Channel To Whom With What Effect atau siapa yang menyampaikan, apa yang disampaikan, melalui apa, kepada siapa, dan apa pengaruhnya.

Sesuai dengan fungsi legis latif yang dimilikinya, setiap anggota Dewan Perwakilan Rakyat Aceh memiliki kesempatan yang sama untuk berbicara mengemukakan informasi, opini, perasaan (seperti rasa tidak sependapat, rasa marah, rasa ragu dan lainnya) sebagai sebuah pesan yang disampaikan. Pada umumnya, pesan politik yang mereka buat disampaikan melalui dua macam saluran (Cangara, 2009: 33). Pertama, saluran komunikasi kelompok, misalnya melalui jalur fraksi atau komisi. Biasaya saluran tersebut digunakan saat dalam berkomunikasi secara tatap muka, seperti saat rapat-rapat maupun diskusi di Dewan Perwakilan Rakyat Aceh. Kedua, saluran komunikasi publik misalnya, aula, balai desa, alunalun dan sebagainya. Saluran kedua ini biasa digunakan oleh Dewan Perwakilan Rakyat Aceh dalam me lakukan kunjungan kerja, reses dan sebagainya.

Melalui kedua saluran tersebut, maka pesan akan ditujuan kepada komunikan. Peneliti melihat bahwa yang menjadi komunikan ada tiga, yaitu angota Dewan Perwakilan Rakyat Aceh itu sendiri, pemerintah dan masyarakat. Pesan yang diterima oleh komunikan diharapkan dapat menciptakan pemahaman terhadap sistem pemerintahan dan partai-partai politik, kesepakatan bersama terhadap kebijakan maupun pencarian solusi atas problema yang menjadi kepentingan masyarakat. Model komunikasi yang dimaksud dapat dilihat melalui ga mbar berikut: 


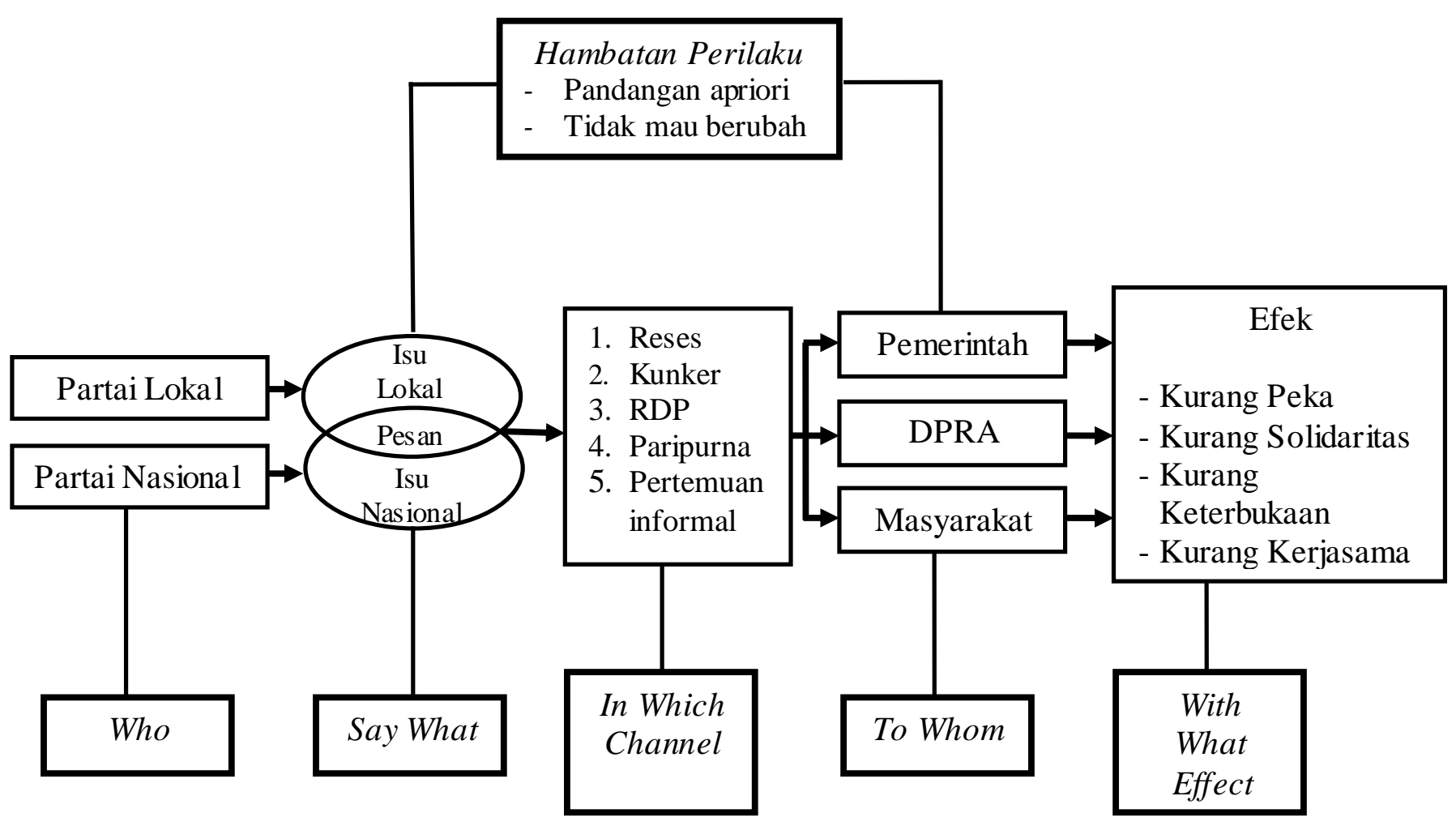

Gambar 2. Model dinamika komunikasi partai nasional dan partai lokal di Dewan Perwakilan Rakyat Aceh (Peneliti, Januari 2020)

Berdasarkan analis is peneliti, Perbedaan kelompok partai yang ada membuat komunikasi diantara anggota Dewan Perwakilan Rakyat Aceh terbatas. Partai nasional tidak akan memasukkan diri untuk melakukan komunikasi terhadap hal-hal atau kebijakan yang berskala lokal. Sebaliknya, partai lokal akan menarik diri untuk membahas persoalan dengan ruang lingkup nasional.

Hal ini dapat dipahami melalui sejarah kemunculan partai lokal di Provinsi Aceh, setelah terbitnya MoU Hels inki Pemerintah Indoneia dengan Gerakan Aceh Merdeka (GAM), dimana dalam butir (1) penyelenggaraan pemerintah di Aceh di poin (1.2) partisipasi politi dije laskan bahwa:

"Sesegera mungkin, tetapi tidak lebih dari satu tahun sejak penandatanganan Nota Kesepahaman ini, Pemerintah Republik Indonesia menyepakati dan akan menfasilitasi pembentukan partai-partai politik yang berbas is di Aceh yang memenuhi persyaratan nasional. Memaha mi aspirasi rakyat Aceh untuk partai-partai politik lokal, Pemerintah Republik Indonesia, dalam tempo satu tahun, atau paling lambat 18 bulan sejak penandatanganan Nota Kesepahaman ini, akan menciptakan kondisi politik dan hukum untuk pendirian partai politik lokal di Aceh dengan berkonsultasi dengan Dewan Perwakilan Rakyat (DPR). Pelaksanaan Nota Kesepahaman ini yang tepat waktu akan memberi sumbangan positif bagi maksud tersebut." (Hamid, 2006: 511)

Keberadaan partai politik lokal di Aceh membawa pengaruh besar dan memegang kendali di Dewan Perwakilan Rakyat Aceh. Hal itu disebabkan kepercayaan masyarakat terhadap partai lokal, yang dapat dibuktikan dengan perolehan suara tertinggi pada pemilihan legis latif tahun 2019 lalu. 


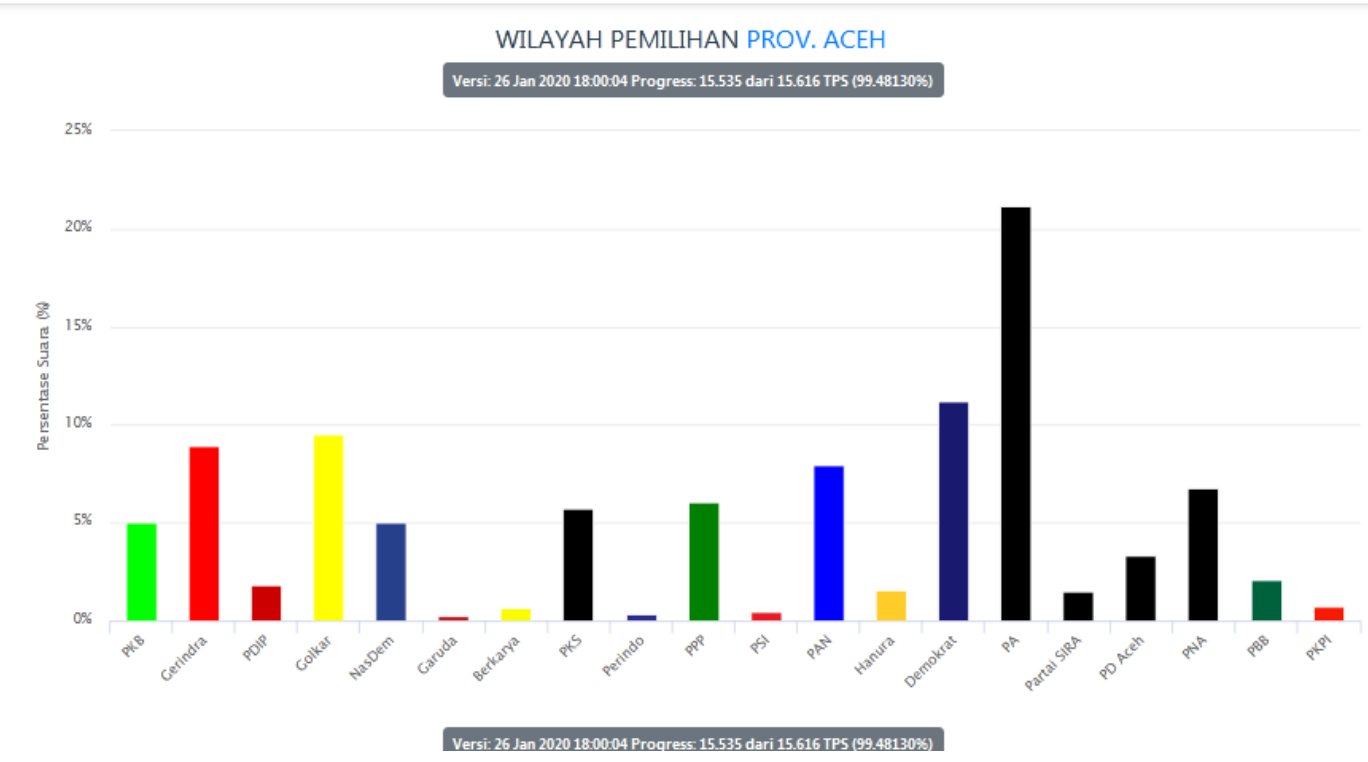

Gambar 3. Perolehan suara legis latif wilayah pemilihan Provinsi Aceh (Info Pemilu, Januari 2020)

Partai Aceh sebagai partai lokal pendulang suara terbanyak (21.16\%) mengalahkan suara partai nasional. Dengan perolehan suara tersebut, partai lokal memegang pengaruh besar di Dewan Perwakilan Rakyat Aceh. Sesuai dengan tujuan utamanya, partai lokal berusaha melakukan upaya untuk memperjuangkan aturan berasas kearifan lokal yang sebenarnya telah dituangkan dalam Undang Undang Republik Indonesia Tentang Pemerintahan Aceh (UUPA) No.11 Tahun 2006 serta dipertegas dalam Qanun Aceh atau peraturan daerah yang mengatur tentang tata pemerintahan dan kehidupan masyarakat di provinsi Aceh.

Perjuangan partai lokal ini pada kenyataannya tidak berjalan lancar. Hal ini disebabkan tidak adanya keinginan antara kedua kelompok tersebut untuk menjalin komunikasi yang terbuka. Meskipun jika dilihat kedua kelompok partai ini berkomunikasi dengan baik, sebenarnya tidak demikian. Khsusunya saat membahas isu-isu lokal.

Isu yang paling kontroversial dan belum mendapat titik temu adalah persoalan Qanun Nomor 3 Tahun 2013 tentang bendera dan lambang Aceh. Terkait Qanun tersebut, peneliti menemukan data sebagai berikut:

"Sebagaimana diketahui, Kementerian Dalam Negeri melalui keputusan Mendagri nomor 188.34-4791 Tahun 2016 tanggal 12 Mei 2016 telah membatalkan dan mencabut beberapa pasal dalam Qanun Nomor 3 Tahun 2013 tentang Bendera dan Lambang Aceh." (Serambi, 2 Agustus 2019)

Partai lokal memperjuangkan diberlakukannya Qanun Bendera karena menganggap hal tersebut merupakan hak otonomi yang diberikan pemerintah Indonesia melalui UUPA Pasal 246 ayat (2) bahwa selain bendera merah putih, pemerintah Aceh dapat menentukan dan me mutuskan bendera dan lambang daerah Aceh sebagai lambang yang mencerminkan keistimewaan dan kekhususan Aceh. Dalam Ayat (3) menjelaskan bahwa bendera sebagai lambang yang dimaksud bukan merupakan simbol ke daulatan dan tidak diberlakukan sebagai bendera kedauatan di Aceh. Yang menjadi polemik adalah bendera dan lambang yang diajukan oleh partai lokal adalah bendera dan lambang yang persis dengan bendera serta lambang Gerakan Aceh Meredeka (GAM). Hal semacam inilah yang kemudian disikapi oleh 
partai nasional sebagai sebuah bahasan dilema. Mereka tidak menolak tapi juga tidak menerima. Sehingga Qanun Bendera dan lambang tersebut tidak diperjuangkan oleh partai nasional yang sebagai partai yang memiliki jaringan kuat di tingkat pusat.

Komunikasi di Dewan Perwakilan Rakyat Aceh juga tidak hanya sebatas pada sesama anggota Dewan Perwakilan Rakyat Aceh saja, melainkan kepada pemerintah dan masyarakat khususnya dengan para konsistuen. Hasil wawancara dan analis peneliti, komunikasi terhadap pemerintah juga terjadi kesenjangan. Hal ini disebabkan oleh kubu kelompok partai politik yang berbeda antara keduanya. Dimana pemerintahan saat ini dipimpin oleh Ir. Nova Iriansyah, MT yang bersandar pada bendera partai Demokrat atau kelompok partai nasional. Kondisi ini membuat Dewan Perwakilan Rakyat Aceh dan Pemerintahan Aceh terus bertolak belakang dan bertahan pada kekuasaan masing-masing. Bukti dari kontroversi mereka ini peneliti temukan dalam pemberitaan di tahun 2017 dengan judul pernyataan Wagub Aceh dinilai memancing keadaan, Abdullah Saleh: Kenapa Nova Iriansyah Menyerang Dewan Perwakilan Rakyat Aceh.

"Nova mengatakan, partai pendukung pemerintah saat ini belum bisa mengalahkan partai penguasa. Dia berharap, PNA, PDA dan PKB bisa menambah kursi dan PDIP juga bisa mengirim perwakilannya ke DPRA. Tentu dengan tidak mengurangi jatah Demokrat. "Di DPRA, merah harus dilawan dengan merah. Biru, kuning, biru muda, hijau belum cukup mampu, jadi kami butuh merah, merah yang lain (PDIP)," pungkasnya." (modusaceh.co, 20 Agustus 2019)

Kutipan pernyataan Nova Iriansyah menunjukkan dengan jelas bahwa untuk melanggengkan misi politik dan program pemerintahan yang dijalankannya, Nova Iriansyah butuh dukungan dari kursi yang dapat mengalahkan partai partai lokal di Dewan Perwakilan Rakyat Aceh. Sementara itu, untuk komunikasi antara anggota Dewan Perwakilan Rakyat Aceh dengan para konsistuennya tetap berjalan seperti sebelum-sebelumnya. Jalinan komunikasi dengan para konsistuen dilakukan dengan reses, kunjungan kerja, dan rapat dengar pendapat.

Komunikasi yang tidak langgeng antara sesama anggota Dewan Perwakilan Rakyat Aceh dan pemerintah menyebabkan model komunikasi yang dibangun Dewan Perwakilan Rakyat Aceh terhadap konsistuen juga tidak maksimal. Sehingga fungsi DPR sebagai wakil rakyat hanya sebatas formalitas mengikuti agenda yang sudah dibuat oleh sekretariat Dewan Perwakilan Rakyat Aceh. Fungsi pengawasan lebih banyak terfokus pada aktivitas pemeriksaan yang berupa kunjungan kerja yang berorientasi pada proyek fisik. Padahal, fungsi pengawasan yang diharap untuk dilakukan oleh anggota Dewan Perwakilan Rakyat Aceh adalah pengamatan yang hasilnya dapat menja di rekomendasi berdasarkan kepentingan masyarakat Aceh. Kondisi ini menimbulkan kecurigaan bagi masyarakat atas fungsi pengawasan dari Dewan Perwakilan Rakyat Aceh yang dapat menjadi tawar menawar atau suka dan tidak suka untuk dilakukan. Anggota Dewan Perwakilan Rakyat Aceh juga lupa untuk memanfaatkan keberadaan media massa secara maksimal, termasuk keberadaan website milik Dewan Perwakilan Rakyat Aceh yang jarang diisi dengan aktivitas serta hasil kinerja dari 81 anggota Dewan Perwakilan Rakyat Aceh. Padahal, dengan memaksimalkan keberadaan media massa dan website milik Dewan Perwakilan Rakyat Aceh dapat menjadi salah satu cara untuk menjalin komunikasi yang baik kepada masyarakat melalui pemberian informasi aktivitas nyata yang dilakukan oleh anggota Dewan Perwakilan Rakyat Aceh.

Peneliti melihat ada hambatan komunikasi yang terjadi antara anggota Dewan Perwakilan Rakyat Aceh sehingga menyebabkan konflik serta hidupnya dua kubu partai yang saling menunjukkan eksistensi dan kekuatannya masing-masing (kubu partai nasional dan kubu partai lokal. Hal ini ditengarai oleh pembagian kewenangan yang belum tegas diatur oleh pemerintah. Dimana diketahui bahwa Aceh sendiri ditetapkan oleh pemerintah Indonesua sebagai wilayah otonomi khusus atau dikenal dengan nama lain symmetric 
decentralization. Berdasarkan keputusan tersebut, maka wilayah Aceh diberi kebebasan untuk mengatur hak, wewenang, dan kewajiban wilayahnya. Termasuk dengan diizinkannya tumbuh partai lokal di Aceh. Selain untuk meredam gejolak, partai lokal dimaksudkan agar Aceh untuk menyuarakan suara kedaerahaan.

Melihat kondisi yang ada, keberadaan partai politik lokal yang berbarengan dengan partai nasional membatasi ruang gerak partai lokal di Aceh untuk melaksanakan programprogram atau pengawasan yang akan mereka canangkan. Hal ini juga ada kaitannya dengan konteks kewenangan otonomi khusus yang diberikan. Secara tidak langsung, pemerintah pusat masih melakukan intervensi sebagai bentuk monitoring agar stabilitas pemerintahan di Aceh tetap terjadi, mengingat pernah terja dinya konflik di Aceh. Namun, di sisi lain keadaan tersebut sebenarnya membuat buruk komunikasi antar anggota Dewan Perwakilan Rakyat Aceh dan pemerintahan Aceh itu sendiri.

Perbedaan kelompok partai yang ada dipahami oleh masing-masing orang sebagai bentuk kompetisi bukan sebagai koalisi yang berpikir untuk membangun Aceh secara bersama. Masing-masing dari anggota Dewan Perwakilan Rakyat Aceh merasa benar dan tidak mau mendengarkan penjelasan dari anggota Dewan Perwakilan Rakyat Aceh lain yang berlainan kelompok, atau disebut dengan pandangan apriori. Seperti yang diungkap oleh informan da lam pene litian ini, setiap kebijakan atau persoalan yang diperjuangkan oleh partai lokal akan didengar namun partai lokal mengaku bahwa partai nasional tidak mau menindak lanjuti persoalan mereka yang condong mengandung isu lokal. Karena perlakuan tersebut, partai lokal pun melakukan hal yang sama dengan tetap memperjuangkan isu lokal dan mengesampingkan isu-isu nasional, karena anggota Dewan Perwakilan Rakyat Aceh dari partai lokal merasa anggota Dewan Perwakilan Rakyat Aceh dari partai nasional tidak mau membantu perjuangan mereka.

Kondisi seperti ini terus dipertahankan dalam setiap periode pemilihan anggota Dewan Perwakilan Rakyat Aceh. Dampaknya, dinamika komunikasi dengan indikator kepekaan, solidaritas, keterbukaan dan kerjasama tidak berjalan dengan maksimal. Hambatan ini disebut dengan hambatan perilaku. Hal ini juga berpengaruh terhadap fungsi legislatif anggota Dewan Perwakilan Rakyat Aceh yang tidak berjalan maksimal karena hanya mengurusi kepentingan dan konflik kelompok partai.

\section{SIMPULAN}

Melalui hasil pene litian dapat disimpulkan bahwa perbedaan kelompok partai yang ada memunculkan komunikasi yang menarik. Dimana komunikasi antara partai lokal dengan partai nasional terbatas, sedangkan partai nasional tidak akan memasukkan diri untuk melakukan komunikasi terhadap hal-hal atau kebijakan yang berskala lokal. Sebaliknya, partai lokal akan menarik diri untuk membahas persoalan dengan ruang lingkup nasional. Akibatnya, diantara kedua kelompok partai tersebut kurang menimbulkan kepekaan, kurang menunjukkan solidaritas, kurang adanya keterbukaan dan kurang kerjasama.

Adapun hambatan komunikasi yang terjadi antara anggota Dewan Perwakilan Rakyat Aceh adalah masing-masing kelompok partai merasa benar dan tidak mau mendengarkan penjelasan dari anggota Dewan Perwakilan Rakyat Aceh la in yang berlainan kelompok, atau disebut dengan pandangan apriori. Dimana setiap kebijakan atau persoalan yang diperjuangkan oleh partai lokal akan didengar namun partai lokal mengaku bahwa partai nasional tidak mau menindak lanjuti persoalan mereka yang condong mengandung isu lokal. Karena perlakuan tersebut, partai lokal pun melakukan hal yang sama dengan tetap memperjuangkan isu lokal dan mengesampingkan isu-isu nasional, karena anggota Dewan Perwakilan Rakyat Aceh dari partai lokal merasa anggota Dewan Perwakilan Rakyat Aceh dari partai nasional tidak mau membantu perjuangan mereka. Kondisi seperti ini terus 
PERSEPSI: Communication Journal

e-ISSN 2623-2669

Vol 3No. 1, 2020, 37-46

DOI: $10.30596 /$ persepsi.v\%vi\% i.4444

dipertahankan dalam setiap periode pemilihan anggota Dewan Perwakilan Rakyat Aceh. Hambatan ini disebut dengan hambatan perilaku.

\section{DAFTAR PUSTAKA}

Efendy, OnongUchana. (2005). Ilmu Komunikasi Teori dan Praktek. Bandung: Remaja Rosda Karya

Surbakti, Ramlan. (2010). Memahami Ilmu Politik. Jakarta: Gramedia Pustaka Utama.

Rush, Michael dan Althoff, Philip. (2008). Pengantar Sosiologi Politik. Jakarta: Rajaw ali Press

Harun, Rochajat dan Sumarno. (2006). Komunikasi Politik Sebagai Suatu Pengantar. Bandung: Mandar Maju.

Nimmo. (1978). Political Communication and Public Opinion In America. California: Goodyear publishing Company.

Cangara, Hafied. (2009). Komunikasi Politik. Jakarta: PT Raja Grafindo Persada.

Budiarjo, Miriam. (2006). Dasar-Dasar Ilmu Politik. Jakarta: PT. Gramedia Pustaka Utama

Rahman, H.I. (2007). Sistem Politik Indonesia. Yogyakarta: Graha Ilmu.

Pemerintah Indonesia. Undang-Undang RI No. 11 Tahun 2006 Tentang Pemerintah Aceh, Lembaran RI Taun 2006 Nomor 62. Jakarta: Sekretariat Negara.

Komisi Pemilihan Umum. (2014). Peraturan Komisi Pemilihan Umum Nomor 21 Tahun2014 Tentang Rekapitulasi Hasil Penghitungan Perolehan Suara Dan Penetapan Hasil Pemilihan Umm Presiden Terpilih Tahun 2014. Jakarta: Sekretariat Jendera KPU.

Arikunto, S. (2006). Metode Penelitian Kualitatif. Jakarta: Bumi Aksara

Sugiyono. (2006). Metode Penelitian Kuantitatif, Kualitatif dan R \& D. Bandung: Alfabeta.

Hamid, Farhan Ahmad. (2006). Jalan Damai Nanggroe Endatu: Catatan Seorang Wakil Rakyat Aceh. Jakarta: Penerbit Suara Bebas.

RI, KPU. (2020). Hasil Perolehan Suara Legislatif Wilayah Pemilihan Provinsi Aceh. https://pemilu2019.kpu.go.id/\#/dprdprov/hitung-suara/.

Modusaceh.co. (2017). Wagub Aceh dinilai memancing keadaan, Abdullah Salh: Kenapa Nova Iriansyah Menyerang DPRA. Aceh: https://modusaceh.co/news/abdullah-saleh-kenapanova-iriansyah-menyerang-dpra/index.html. 20 Agustus. 